\title{
Ecology and decay pattern of Inocutis dryophila in Quercus robur
}

\author{
STELLAN SUNHEDE and RIMVYDAS VASILIAUSKAS
}

SUNHEDE, S. \& VASILIAUSKAS, R. 2003. Ecology and decay pattern of Inocutis dryophila in Quercus robur. - Karstenia 43: 45-53. Helsinki. ISSN: 0435-3402.

\begin{abstract}
The biology of Inocutis dryophila (Berk.) Fiasson \& Niemelä was studied on Quercus robur L. in Lithuania, based on 22 host trees. Decay columns caused by the fungus in six oaks, 120-180 years old, were examined in detail by dissecting the stems. Length of the decay columns in different trees varied between 4.8 and $11 \mathrm{~m}$. Vegetative compatibility tests with the isolates indicated that each rot column comprised of a single genet of the fungus, and that the rot columns in different trees represented different genets. Basidiocarps of the fungus were recorded from 0.7 to $12.5 \mathrm{~m}$ above the ground. Infection routes, forestry, and biodiversity aspects are discussed. Colour photographs are shown of the basidiocarp, decay of different stages, and confrontation tests among cultivated mycelia of the same and different genets.
\end{abstract}

Keywords: Biodiversity, decay, ecology, forest pathology, Inocutis dryophila, Lithuania, Quercus robur, compatibility

Stellan Sunhede, Department of Natural Sciences, University of Skövde, P.O. Box 408, SE-54I 28 Skövde, Sweden

Rimvydas Vasiliauskas, Department of Forest Mycology and Pathology, Swedish University of Agricultural Sciences, P.O. Box 7026, SE-750 07 Uppsala, Sweden

\section{Introduction}

Inocutis dryophila (Berk.) Fiasson \& Niemelä (Inonotus dryophilus (Berk.) Murr.) is a circumboreal polypore of the North Temperate Zone, mainly occurring on living oaks (Ryvarden and Gilbertson 1993). Fiasson and Niemelä (1984) placed the fungus in the family Inonotaceae of Hymenochaetales. They transferred the species from Inonotus to the new genus Inocutis together with Inonotus rheades (Pers.) P. Karst. and Inonotus tamaricis (Pat.) Maire, which also possess a duplex trama with a grainy, marmorated core. For detailed description of the morphology and characteristics of the species see Gilbertson and Ryvarden (1986) as well as Ryvarden and Gilbertson (1993).
In the U.S.A., I. dryophila is a major cause of decay in several species of Quercus (Hepting 1971), and it was reported to be particularly destructive in the Southwest and on the Pacific Coast (Boyce 1938). In these parts and in some of the southern states the majority of living oaks representing 14 different species were so badly decayed or hollowed by I. dryophila that they were of no use except for the low quality fuel (Hedgcock \& Long 1914). More recent studies in central U.S.A. revealed the presence of the fungus in $1.4 \%$ of 3000 living oaks examined (Berry \& Lombard 1978).

In Europe, the species is usually found on Quercus petraea (Matt.) Liebl. and Q. robur L., 
and sometimes on other hardwoods such as Eucalyptus and Fraxinus (Kotlaba 1984, Ryvarden \& Gilbertson 1993). In Europe, I. dryophila is generally regarded as a rare fungus (Breitenbach \& Kränzlin1986). Its rarity was noted particularly in countries situated in northern and central parts of the continent: Sweden (Ryman \& Holmåsen 1991), Finland (Niemelä \& Kotiranta 1982, Kotiranta \& Niemelä 1996), Estonia (Parmasto 1993), Latvia (Rafalovich 1967, Smarods 1953), Lithuania (Mazelaitis 1976, Gricius \& Matelis 1996), Belarus (Komarova 1964), Poland (Domanski et al. 1973), Czech Republic and Slovakia (Kotlaba 1973), and Germany (Jahn 1979). The fungus has not been found in Denmark and Norway (Sunhede 1997). Therefore, I. dryophila is red-listed in Sweden, Finland, Poland, Germany (Sunhede 1997), and Lithuania (Balevicius et al. 1992).

From some of the mentioned countries there are reports that $I$. dryophila may sometimes appear as an economically important forest pathogen. Aufsess (1973) reported that due to the frequent occurrence and strong destructive ability of $I$. dryophila, the fungus might be regarded as a serious pathogen of oak in some parts of Germany. According to Černy (1989), over 5\% of the oaks were infected by the fungus in certain parts of the Czech Republic and Slovakia, causing serious loss in wood production. Previously, I. dryophila had only been found twice in Lithuania and was regarded as very rare (Mazelaitis 1976, Gricius \& Matelis 1996). However, a recent study concentrating exclusively on oak stands, revealed 22 new finds in Lithuania (Sunhede \& Vasiliauskas 2003).

In general, the fungus seems to be very rare throughout the western parts of Russia and adjacent countries (Bondartseva \& Parmasto 1986). Bondartsev (1971) also noted only scattered occurrence of I. dryophila in western parts of European Russia, but an increasing frequency towards the east. In fact, I. dryophila was reported as one of the most important decayers of living oak in the Tula region $200 \mathrm{~km}$ south of Moscow, where it was found on $1.7 \%$ of trees in middle-aged and premature stands (Granatov 1973). Early studies, conducted about $800 \mathrm{~km}$ further eastwards, had revealed that $25 \%$ or even $70-80 \%$ the of oaks were infected by the fungus in stands along the river Volga (Vanin 1929, Vakin 1932). A frequent occurrence of $I$. dryophila in oak stands of Volga basin was later confirmed by Yupina (1987) and
Churakov (1992). They also claimed I. dryophila to be one of the most important decayers of living oak in the region.

By contrast, only scattered finds of $I$. dryophi$l a$ have been reported from parts of Europe bordering Asia, as in southern Ural (Stepanova-Kartavenko 1967) and Trans-Caucasia (Melik-Khachatryan \& Martirosyan 1971). In Asia, according to available data, this species seems to be very rare. The fungus is not known from China and Pilát's (1940) report is based on an misidentification (Dai et al. 1997). During the studies of wood-inhabiting fungi in the Russian Far East, the species was only found once in Southern Sakhalin (Lyubarskiy \& Vasilyeva 1975).

Despite the importance of I. dryophila for nature conservation and/or forestry in many countries, data regarding its ecology and decay patterns are scarce. The aim of the present study is to add detailed information on the ecology, decay patterns, population structure, biology, and silvicultural significance of the species.

\section{Material and methods}

During the fieldwork in Lithuania 5455 trees and 742 stumps of felled trees of Quercus robur were studied, with special emphasis on Inocutis dryophila. Position and number of basidiocarps of the fungus on the oaks, damages on the trees, and the diameter of the stem (1.3 $\mathrm{m}$ above the ground) were registered. The collections of I. dryophila in the herbarium BILAS at the Botanical Institute in Vilnius were also examined.

In a special study, six trees of Quercus robur attacked by the fungus, were felled in the Panevezys Region of Lithuania (in places where other host trees could be left intact). After general registrations (cf. above) the trees were cut with a chainsaw, thus enabling study of rot distribution and sampling of decayed wood for cultivation of vegetative mycelia. The procedure followed Sunhede and Vasiliauskas (2002) except for counting of tube layers in the basidiocarps. In addition, tree roots were sectioned to make it possible to follow a descending rot in one case. Characteristics of the felled trees are presented in Table 1.

From different parts of the decay columns isolates of I. dryophila were obtained. The number of samples varied between two to thirteen ( 29 in total, or 5 per tree on average). The mycelia were used for vegetative incompatibility tests to see if one or several individual mycelia (genets) were present in the same trunk. Self-compatibility tests and tests with mycelia from different sections and trees (from the same or distant localities) were made to study non-confrontation and confrontation zones. The results of the compatibility tests were compared with field observations of the decay in the sectioned trunks. 
Table 1. Main parameters of analysed Quercus robur trees and Inocutis dryophila decay columns.

\begin{tabular}{lccccc}
\hline \multicolumn{2}{l}{ Tree parameters } & & \multicolumn{2}{c}{ Decay column parameters" } \\
\hline No. & $\begin{array}{c}\text { Diameter at breast } \\
\text { height }(\mathrm{cm})\end{array}$ & Height $(\mathrm{m})$ & \multicolumn{2}{c}{ Limits in stem (m) } & $\begin{array}{c}\text { Total length } \\
(\mathrm{m})\end{array}$ \\
\cline { 4 - 5 } & & & Lower & Upper & \\
\hline 1. & 67 & 24.5 & 0 & 9.8 & 9.8 \\
2. & 30 & 12.5 & 0 & 11.0 & 11.0 \\
3. & 48 & 26.0 & 8.1 & 16.8 & 8.7 \\
4. & 43 & 22.6 & 1.8 & 10.3 & 8.5 \\
5. & 44 & 26.2 & 4.6 & 9.9 & 5.3 \\
6. & 55 & 25.1 & 4.9 & 9.7 & 4.8 \\
\hline Mean & 48 & 22.8 & 3.2 & 11.3 & 8.0 \\
S & 13 & 5.2 & 3.2 & 2.8 & 2.5 \\
\hline
\end{tabular}

Analysed trees were 120-180 years-old, all living except number two.

One genet of the fungus was observed in each analysed tree.

\section{Results}

\section{DISTRIBUTION}

We found Inocutis dryophila on oak trees with a diameter between 0.3 and $1.0 \mathrm{~m}$. Trees were located in central and southeast Lithuania, in the districts of Alytus, Kaunas, Panevézys, and Vilnius. The species was found in pure oak stands, mixed deciduous woods, in a wooded meadow, and in a park.

\section{BASIDIOCARPS}

Basidiocarps were found on $22(0.4 \%)$ of the 5455 oaks investigated. All host trees were living except one dead, standing trunk with strongly decayed wood (Figs 1,2). No basidiocarps were found on the 742 investigated stumps from felled oaks.

Basidiocarps were observed from 0.7 to $12.5 \mathrm{~m}$ above the ground on the standing tree and once on a thick, fallen branch. They occurred on barkclad wood, on healing wounds, or at the base of dead attached branch-stubs. Only one or two basidiocarps of the season were found on each tree (Fig. 1). However, the annual basidiocarps remained partly intact to the next season and remnants (especially the hard core of the duplex trama) were found to persist for a longer time.

\section{DECAY OF SECTIONEDTREES}

The following description of decay is based on the observations of cross- and longitudinal sections of the trunks, branches and roots.

The first indication of Inocutis dryophila in cross-sectioned wood are \pm distinct, dark spots on wood as hard as the surrounding tissue. Within these dark areas small whitish spots or strands appear (Fig. 4: arrows). In time, the whitish spots and strands of decayed wood increase in size mainly following the early wood of the annual rings. Decomposition of xylem rays and part of late wood also occurs. Separate, decayed parts later merge together, forming a mottled (marbled) pattern of soft whitish and hard dark wood (Fig. 4). The wellestablished mycelium forms \pm broad, concentric rings of decayed wood in the \pm unaffected wood from the centre of the trunk to the border of the splint wood. In longitudinal section the wood at this stage shows whitish prolonged spots or strands of cellulose together with moist, hard, darkbrown wood (Fig. 3). In late stages of decay the whitish pattern of cellulose disappears and the rot becomes brownish consisting of rather fragile, long strands or flakes of wood remains (Fig. 2). 

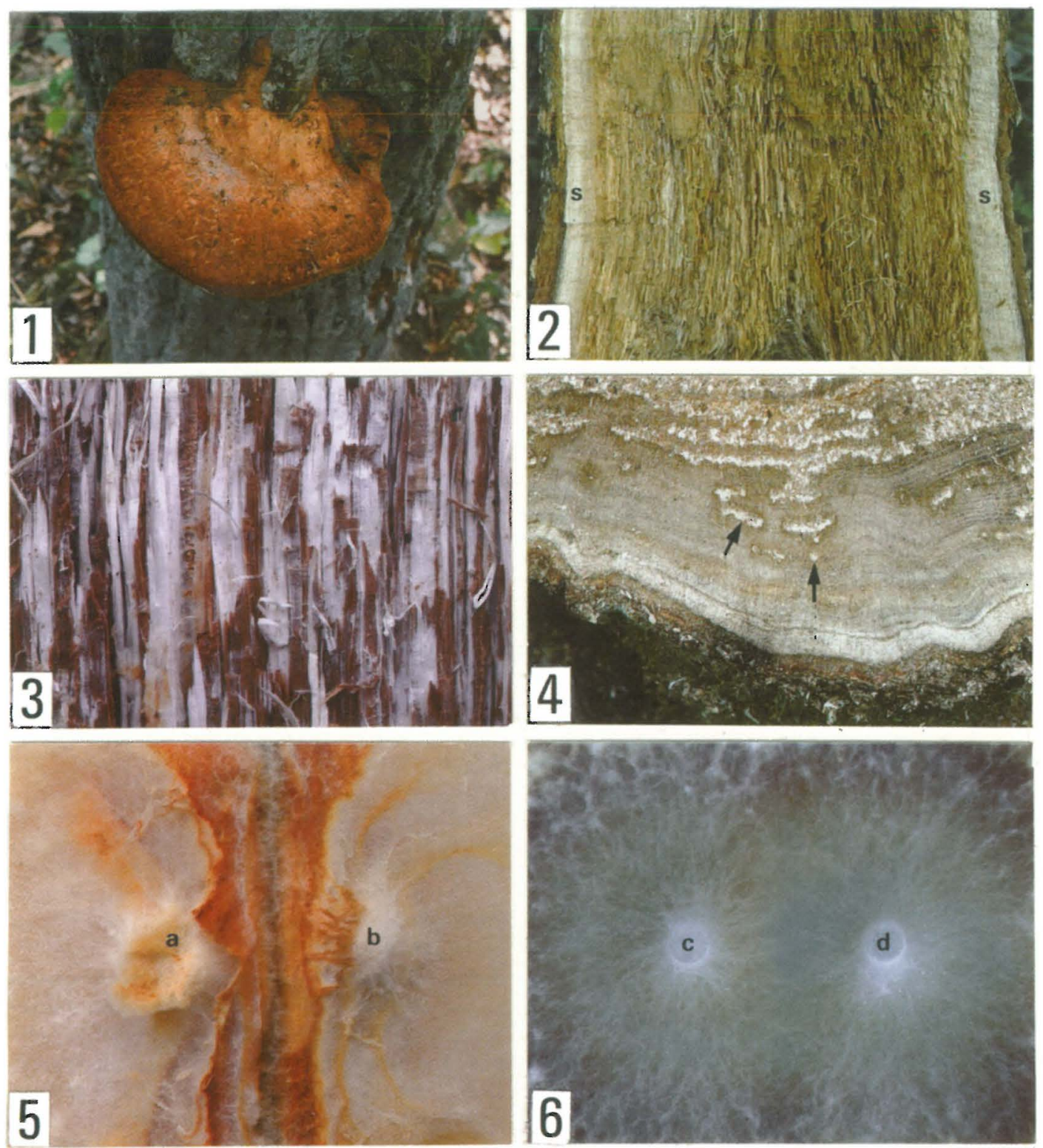

Figs 1-6. Mycelial activities of Inocutis dryophila. - 1: Basidiocarps, attached $0.9 \mathrm{~m}$ above the ground, on a dead, standing, $30 \mathrm{~cm}$ thick trunk of Quercus robur. - 2: Vertical median section of the trunk in (1) at the approximate level of the basidiocarp with a central, advanced, old rot of the fungus bordered by a thin, whitish layer of sap-wood with attached bark. - 3: Vertical central section of the basal part of a $67 \mathrm{~cm}$ wide trunk of a living oak, showing an active rot with white patches of cellulose. - 4: Stump of the same tree showing the light cellulose pattern horizontally sectioned. - 5: Confrontation zone between two genetically different mycelia grown on Hagem agar, inoculated at (a) and (b), respectively. - 6: Isolates from a single genet (c) and (d), respectively. - 1: Lithuania, Panevézys, Pereksliai, 9.8.1984. - 3, 4: Panevézys, Gustonys, 4.8.1995. - Photo: Stellan Sunhede. 

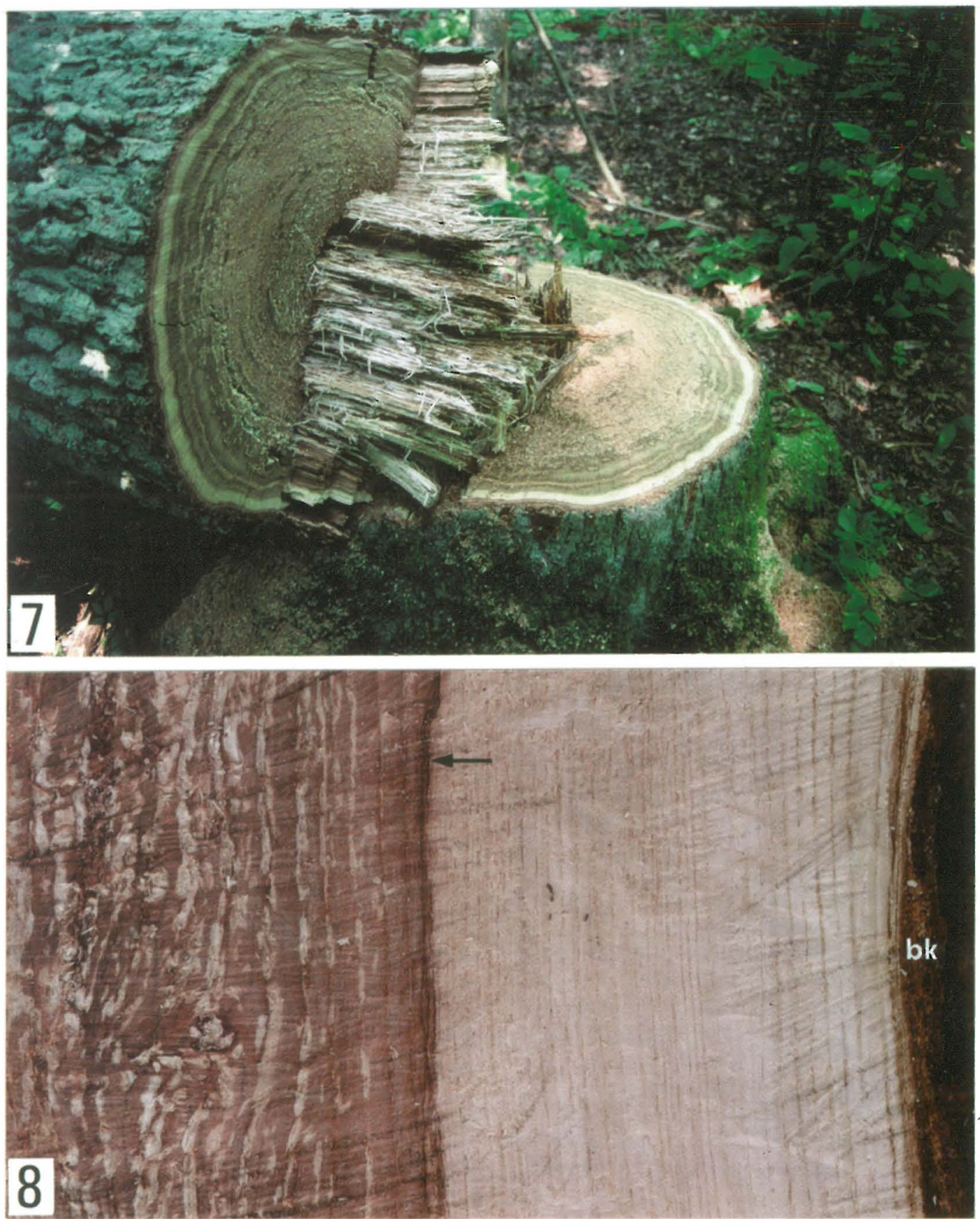

Figs 7-8. Decay of Inocutis dryophila in sectioned stems of Quercus robur. - 7: Felled trunk and stump with almost all wood strongly decayed except for a thin layer of sapwood next to the bark. Decay descending into the roots of a stump. - 8: Longitudinal section showing rot columns of $I$. dryophila (left) and Phellinus robustus (right), separated by a dark brown border line (arrow). - bk = bark and dead cambium. - 7: Panevézys, Gustonys, 4.8.1995. - 8: Panevézys, Naujamiestis, 8.8.1995. - Photo: Stellan Sunhede. 
Decay was observed both in the centre of the trunk growing towards the splint wood (Fig. 4) and in the periphery of the heartwood growing towards the centre of the stem. The decay advanced both upwards and downwards from the infection site. In two trees the decay reached the base of the stem and continued out into the thick roots (Fig. 7). In trunks with a late stage of rot almost all wood was strongly decayed except for a thin layer of sapwood next to the bark (Fig. 2: s). The vertical extension of the decay columns varied between 4.8 and $11.0 \mathrm{~m}$ (Table 1). We have also observed decay in thicker branches.

Four of the trees infected by Inocutis dryophila were also attacked by Phellinus robustus (Bull. : Fr.) Karst. In one of these trees the different rots occurred side by side in well distinguished rot columns (Fig. 8).

\section{MYCELIA AND GENETS}

In cultures on Hagem agar, the vegetative mycelium grew both along the surface and submerged. The aerial mycelium was cottony with depressed centre, whitish to pale ochraceous. The submerged mycelium advanced faster than the aerial.

In self-compatibility tests the compatible mycelia merged and no borderline was formed between the two isolates (based on 53 pairings; Fig. 6). There was no change in colour of the agar but it turned brownish along the periphery (Fig. 6). When incompatible mycelia met, a distinct confrontation zone developed as a ditch with elevated margins and it became distinctly rusty red (based on 45 pairings; Fig. 5).

Confrontation tests among mycelial isolates from a single rot column showed no confrontation zone (based on 125 parings) and were identical to the self-pairings of the same mycelium. When mycelia from different trees were confronted with one another, all pairings showed a distinct confrontation zone. These results indicate that each rot column consisted of a single genet and that the rot columns in different trees represented different genets.

\section{Discussion}

During the work basidiocarps of I. dryophila were found at the bases of attached remnants of dead branches or on healing branch stubs. This indicates that dead branches are the main entrance of the fungus into the host tree, which is in accordance with the observations of several other authors (Hedgcock \& Long 1914, Bondartsev 1971, Čerńy 1989). For example, Berry and Lombard (1978) found that among totally 13 infections of $I$. dryophila, $11(85 \%)$ were associated with branch stubs or broken branches, and only two with damaged or dead tops. Consequently, the decay was in most cases situated in the upper portion of the trunk (Long 1913, Hedgcock \& Long 1914, Boyce 1938). Berry and Lombard (1978) reported that only one out of 13 infections occurred in a butt, the remaining $12(92 \%)$ being located higher up in the trunk. This is well in line with our data. The decay at stump level was observed in 2 out of 6 trees examined (or $33 \%$ ). In both these cases the column was stretching up to 10-11 $\mathrm{m}$ high along the stem (Table 1).

In contrast, data obtained in central parts of Russia indicate a somewhat different behaviour of the fungus. In trees examined by Granatov (1973), the decay column was most often situated at the lower part of the stem: in $59 \%$ of the cases it was found within the lowest quarter reaching the stump level in $61 \%$ of the examined trees. According to the author, the infections were often taking place through frost cracks located at the butt. He also explains the high frequency of the fungus (see Introduction) by the common occurrence of winter frosts in the region, down to $-40^{\circ} \mathrm{C}$. Other Russian studies also indicate that mechanical damage on the lower part of a stem might be an important infection route for I. $d r y$ ophila. Thus, in studies by Yupina (1987) and Churakov (1992), the occurrence of I. dryophila in oak stands was positively correlated with damages caused by recreational and other anthropogenic impact. Also Hedgcock and Long (1914) pointed out that the fungus might enter trees through the basal wounds.

It has previously been reported that following the penetration into the stem $I$. dryophila spreads rapidly in all directions. Bondartsev (1971) noted that the decay column might be over $6 \mathrm{~m}$ long and spread all over the cross-section of the trunk, except a thin layer of sapwood. This is in line with our observations (Figs 2, 7). However, our work has revealed a much larger length of $I$. dryophila decay, often exceeding $8 \mathrm{~m}$ along the tree trunk (Table 1). Also, each of the extensive decay columns comprised only a single individual of the fungus. We may conclude that I. dryophila in 
many cases represents a large fungal organism, which with its physical boundaries is able to occupy several cubic meters of wood. The presence of one genotype of $I$. dryophila per infected tree also indicates that the access for the fungus into the stem is rather restricted. This observation has previously been made in old oaks infected by Laetiporus sulphureus (Bull. : Fr.) Murr. (Sunhede \& Vasiliauskas, unpublished), and (in most cases) by $P$. robustus (Sunhede \& Vasiliauskas 2002). In contrast, several genotypes of Phellinus tremulae (Bond.) Bond. \& Boriss. were usullay found to inhabit a single stem of aspen (Holmer et al. 1994).

Some authors note that $I$. dryophila is a parasite of living trees (DomaDski et al. 1973, Jahn 1979, Gricius \& Matelis 1996). However, Boyce (1938) and Bondartsev (1971) emphasized that the fungus is not capable of invading the sapwood and that the decay caused by the fungus is confined to heartwood of living oak. Interestingly, Černy (1989) indicated that also the sapwood was attacked, leading to decrease in increment and crown decline. This was not observed during our work. I. dryophila decayed the dead heartwood, leaving the sapwood and cambium intact (Figs 2, 7). Therefore, the main pathological consequence of an I. dryophila attack seems to be that a large portion of the attacked trunk is turned into low quality wood (Hedgcock \& Long 1914, Bondartsev 1971).

According to Granatov (1973), the average volume of the decay column of $I$. dryophila in trunks of oak was estimated to $0.110 \mathrm{~m}^{3}$, and was about two and four times higher than that caused by $L$. sulphureus and $P$. robustus, respectively. Therefore, I. dryophila attacks led to the highest loss of saw timber - on average $0.276 \mathrm{~m}^{3}$ per stem, or $54 \%$ of its total timber volume; for $P$. robustus, the corresponding figures were much lower, 0.177 $\mathrm{m}^{3}$ and $36 \%$ (Granatov 1973). Also Aufsess (1973) concluded, that $I$. dryophila should be regarded as a far more destructive pathogen of oak than $P$. robustus. The results of our work indicated the same. As presented in the Table 1, the mean length of $I$. dryophila decay in this study was $8 \mathrm{~m}$. In a similar work carried out by us on P. robustus and L. sulphureus, the average length of decay columns was 3.3 and $2.5 \mathrm{~m}$, respectively (Sunhede \& Vasiliauskas 2002, unpublished). Granatov (1973) reported that in oaks attacked by I. dryophila, volume of decay column as well as volume of the degraded wood were positively correlated with the diameter of the tree $(r=0.62 ; p<0.01)$. In our work, correlation between the stem diameter and length of decay in 5 living stems (Table 1), although positive, was low $(r=0.34)$ and statistically non-significant. More data pairs are therefore required to elucidate a possible correlation between those parameters.

Boyce (1938) noted that decay might sometimes continue to develop slowly for some years after an infected tree dies. Although Hedgcock and Long (1914) usually found fruitbodies on living oaks, in some cases the fruitbodies were also observed on stems and larger branches of trees which had been cut for at least three years, and in one instance the fruitbody was found growing directly on the top of an old stump. They concluded, that the fungus apparently continues to grow slowly in the infected trees after cutting, but rarely fruits under such conditions. Results of the experiment by Hepting and Roth (1950) supported this: when living oaks with fruitbodies were cut, no fruiting was observed for more than 10 years. These data agree with our results, where fruitbodies were observed to fruit on recently, dead substrate in only two out of 22 cases (a trunk and a fallen branch, respectively).

Davidson et al. (1942) described the rot of $I$. dryophila as "white piped rot". The decay in Fig. 3 shows whitish strands of cellulose, which may be removed by a pincer leaving empty "pipes" of various length and shape. Under laboratory conditions, I. dryophila grows well on dead wood and starts to decompose the lignin component in the cell walls soon after infection: in five months the fungus decomposed over $30 \%$ of the wood material (Aufsess 1973). The ability of delignifying dead wood growing on some other hardwoods, such as Eucalyptus and Fraxinus (Ryvarden \& Gilbertson 1993), may contain the potential for its use in a biological pulping process (Otjen \& Blanchette 1982). In late stages of decay, the wood turn brownish (Fig. 2). Gilbertson and Ryvarden (1986) and Ryvarden and Gilbertson (1993) noted that conspicuous brown mycelium of $I$. dryophila develops in the decayed wood in the later stages of decay. That was not observed in our material. 


\section{FORESTRY ASPECTS}

Host trees with $I$. dryophila often look healthy. The annual basidiocarps might be overlooked as they are rather dull-coloured, often situated high up on the trunk, and do not show up every year. In order to reduce the decay losses, the removal of stems with fruitbodies of I.dryophila had been suggested (Hedgcock \& Long 1914, Granatov 1973, Čerńy 1989). However, as indicated by our study, trees with fruitbodies have already a well developed rot column in the stem, making removal by sanitary felling not economically feasible. According to Granatov (1973), I. dryophila more often attacks trees of lower quality. Moreover, the fungus is rare in Lithuania and thus of almost no economic importance to the forestry.

The fungus was red-listed in Lithuania by Balevicius et al. (1992) based on two known sites (Mazelaitis 1976). Our new finds show that the species is more frequent than earlier believed in Lithuanian oak woods, although still regarded as rare. The species is still care demanding and we recommend host tree with $I$. dryophila to be saved in Lithuanian forests.

\footnotetext{
Acknowledgements: We are very grateful to Prof. Albertas Vasiliauskas who made it possible for us to carry out the fieldwork in Lithuania during 1993 to 1996 . We are also indebted to Drs Antanas Matelis, Jurga Motiejunaite and Vincentas Urbonas for excursions made during 1993 and for valuable help in the botanical herbarium (BILAS) in Vilnius. The support from local forest administrators and foresters has highly facilitated the field work. Especially we want to thank Algimantas Burda and Jonas Dumbra. We also owe our gratitude to professors Erast Parmasto and Jan Stenlid for valuable information and Uno Eliasson, Nils Hallenberg, and Tuomo Niemelä for critical reading of the manuscript. Jan Stenlid generously put laboratory facilities at our use. We are grateful to the Ministry of Forestry of Lithuania, the Kapten Carl Stenholms Fond, The Royal Society of Arts and Sciences in Göteborg, and The Swedish Institute for financial support.
}

\section{References}

Aufsess, H.V. 1973: Einige Pilzschäden an alten Eichen. - Forstw. Centralblatt 92: 153-169.

Balevicius K., Lapelè M., Paltanavicius S. \& Ladyga A. (eds) 1992: Lietuvos raudonoji knyga. Red data book of Lithuania. - Vilnius. 364 pp.

Berry, F.H. \& Lombard, F.F. 1978: Basidiomycetes associated with decay of living oak trees. - USDA Forest Service Research Paper NE-413: 1-8.

Bondartsev, A .S. 1971: The polyporaceae of the European USSR and Caucasia (Trutovye griby evropeyskoy chasti SSSR i Kavkaza - Izdatel'stvo Akad. Nauk SSSR, Moskva \& Leningrad. 1106 pp.). - Jerusalem. $896 \mathrm{pp}$.

Bondartseva, M.A. \& Parmasto E.H. 1986: Opredelitel gribov SSSR. Aphyllophorales. - Nauka, Leningrad. 192 pp.

Boyce, J.S. 1938: Forest pathology. - McGraw-Hill, New York. 600 pp.

Breitenbach, J. \& Kränzlin, F. 1986: Fungi of Switzerland. - Mykologia, Luzern. 412 pp.

Čerńy, A. 1989: Parazitické drevokazné houby. - Statní zemědelski nakladatelstvo, Praha. 99 pp.

Churakov, B.P. 1992: Vlijanie rekreatsionnykh nagruzok na porazhaemost duba (Quercus robur) trutovymi gribami v lesakh srednei Volgi. - Lesnoi Zhurnal 2: 116-118.

Dai, Y.C., Niemelä, T. \& Zang, M. 1997: Synopsis of the genus Inonotus (Basidiomycetes) sensu lato in China. - Mycotaxon 65: 273-283.

Davidson, R. W., Campbell, W. A. \& Blaisdell Vaughn, D. 1942: Fungi causing decay of living oaks in the Eastern United States and their cultural identification. - U. S. Dept. Agr. Tech. Bull. 785: 1-75.

Domański, S., Orłoś, H. \& Skirgiełło, A. 1973: Polyporaceae 2. - Ganodermataceae, Bondarzewiaceae, Boletopsidaceae, Fistulinaceae. - Warsaw. 332 pp. \& 27 tables.

Fiasson, J.L. \& Niemelä, T. 1984: Hymenochaetales: a revision of the Europaean poroid taxa. - Karstenia 24: $14-28$.

Gilbertson, R.L. \& Ryvarden, L. 1986: North American Polypores 1. Abortiporus - Lindtneria. - Fungiflora, Oslo. 433 pp.

Granatov, L.B. 1973: Vazhneyshije gnilevye zabolevanija duba v Tulskikh zasekakh i biologicheskije osobennosti ikh vozbuditelei. (Most important decays of oak in Tula region and biological features of decay-causing fungi). - (Summary of doctoral thesis). Moskva. 26 pp.

Gricius, A. \& Matelis, A. 1996: Mycota Lithuaniae VI Aphyllophorales 2. - Hymenochaetaceae, Fistulinaceae, Ganodermataceae, Polyporaceae. - Mokslo ir enciklopediju leidykla, Vilnius. 232 pp.

Hedgcock, G.G. \& Long, W.H. 1914: Heart-rot of oaks and poplars caused by Polyporus dryophilus. - J. Agricultural Res. 3: 65-82.

Hepting, G.H. 1971: Diseases of forest and shade trees of the United States. - U. S. Dept. Agr. Forest Service Agriculture Handbook 386: 1-658.

Hepting, G.H. \& Roth, E.R. 1950: The fruiting of heartrot fungi on felled trees. - J. Forestry 48: 332-333. 
Holmer, L., Nitare, L. \& Stenlid, J. 1994: Population structures and decay pattern in Phellinus tremulae as determined by somatic inompatibility. - Canadian J. Bot. 72: 1391-1396.

Jahn, H. 1979: Pilze die an Holz wachsen. - Busse, Herford. $268 \mathrm{pp}$.

Komarova, E.P. 1964: Opredelitel' trytovykh gribov Belorusii. - Nauka i Tekhnika, Minsk. 343 pp.

Kotiranta, H. \& Niemelä, T. 1996: Uhanalaiset käävät Suomessa. - Edita, Helsinki. 184 pp.

Kotlaba, F. 1973: O dvou vzácných rezavcích na dubech v eskoslovensku: Inonotus dryadeus (Pers.: Fr.) Murr. a I. dryophilus (Berk.) Murr. - Česká Mykol. 27: 6983.

Kotlaba, F. 1984: Zempisné rozš̃̃rení a ekologie chorošů / Polyporales s.l./ v Československu. - Academia, Praha. 194 pp.

Long, W.H. 1913: Three undescribed heart-rots of hardwood trees, especially of oak. - J. Agricultural Res. 1: 109-128.

Lyubarskiy, L.V. \& Vasilyeva, L.N. 1975: Derevorazrushajuschije griby Dalnego Vostoka. - Nauka, Novosibirsk. $218 \mathrm{pp}$

Mazelaitis, J. 1976: Lietuvos TSR Afiloforieciu eiles grybai. - Mokslas, Vilnius. 379 pp.

Melik-Khachatryan, D.G. \& Martirosyan, S.N. 1971: Mikoflora Armianskoi SSR. 2. Gasteromicety i afilloforovye griby. - Izdatelstvo Erevanskogo Univ., Erevan. 383 pp

Niemelä, T. \& Kotiranta, H. 1982: Polypore survey in Finland 2. The genus Phellinus. - Karstenia 22: 27 42.

Otjen, L. \& Blanchette, R.A. 1982: Patterns of decay caused by Inonotus dryophilus (Aphyllophorales: Hymenochaetaceae), a white-pocket rot fungus of oaks. - Canadian J. Bot. 60: 2770-2779.
Parmasto, E. 1993: Distribution maps of Estonian fungi. Eesti seente levikuatlas. 1. Hymenochaetaceae taelikulised. - Tartu 1993.

Pilát, A. 1940: Basidiomycetes Chinenses. - Ann. Mycol. 38: 61-82.

Rafalovich, L. 1967: On polypore fungi flora in Latvian SSR. - Latvijas PSR Zinatnu Academija Vestis 3 (236): 91-95.

Ryman, S. \& Holmảsen, I. 1991: Svampar. En fälthandbok. - Interpublishing, Stockholm. 718 pp.

Ryvarden, L. \& Gilbertson R.L. 1993: European polypores 1. Abortiporus - Lindtneria. - Fungiflora, Oslo. $388 \mathrm{pp}$.

Smarods, J. 1953: Some new data about Hymenomycetes of the Latvijan SSR. - Latvijas PSR Zinatnu Academija Vestis 2 (67): 61-73.

Stepanova-Kartavenko, N.T. 1967: Afilloforovye griby Urala. - Trudy Instituta Ekologii Rasteniy i Zhivotnykh (Uralskiy Filial AN SSSR) 50: 1-293.

Sunhede, S. 1997: Inonotus dryophilus. - In: Larsson, K.H. (ed.), Rödlistade svampar i Sverige; artfakta: 328.

Sunhede, S. \& Vasiliauskas R. 2002: Ecology and decay pattern of Phellinus robustus in old-growth Quercus robur. - Karstenia 42: 1-11.

Sunhede, S. \& Vasiliauskas, R. 2003: Hotade tickor på ek i Litauen. - Svensk Bot. Tidskr. 97:252-265.

Vakin, A.T. 1932: Gribnye bolezni i drugye poroki dubrav po issledovaniju v Chuvashskoy ASSR. - Goslestekhizdat, Moskva. 127 pp.

Vanin, S.I. 1929: Glavneyshie gribnye bolezni Buzulukskogo bora Samarskoy gubernii. - Mat. Mikol. Fitopatol. (Leningrad) 8: 238-254.

Yupina, G.A. 1987: Derevorazrushajuschije griby antropogennykh territorij. - Mikol. Fitopatol. 21: 224225 . 